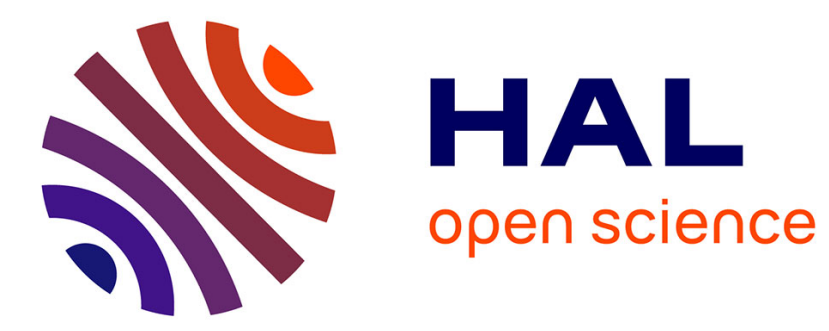

\title{
Application of TRIZ and Innovation Management Theory on Decision Support for Transport Infrastructure
}

Giacomo Bersano, Pierre-Emmanuel Fayemi

\section{To cite this version:}

Giacomo Bersano, Pierre-Emmanuel Fayemi. Application of TRIZ and Innovation Management Theory on Decision Support for Transport Infrastructure. 19th International TRIZ Future Conference (TFC), Oct 2019, Marrakesh, Morocco. pp.486-493, 10.1007/978-3-030-32497-1_38 . hal-02905568

\section{HAL Id: hal-02905568 \\ https://hal.inria.fr/hal-02905568}

Submitted on 23 Jul 2020

HAL is a multi-disciplinary open access archive for the deposit and dissemination of scientific research documents, whether they are published or not. The documents may come from teaching and research institutions in France or abroad, or from public or private research centers.
L'archive ouverte pluridisciplinaire HAL, est destinée au dépôt et à la diffusion de documents scientifiques de niveau recherche, publiés ou non, émanant des établissements d'enseignement et de recherche français ou étrangers, des laboratoires publics ou privés.

\section{(c)(1)}

Distributed under a Creative Commons Attribution| 4.0 International License 


\title{
Application of TRIZ and innovation management theory on decision support for transport infrastructure
}

\author{
Giacomo Bersano ${ }^{1[\text { IKOS Consulting] }}$ Pierre-Emmanuel Fayemi ${ }^{1[\text { IKOS Consulting] }}$ \\ ${ }^{1}$ IKOS Consulting, 155 rue Anatole France, 92300 Levallois Perret, FR \\ lncsespringer.com
}

\begin{abstract}
Design Theory and Innovation management theory are commonly used in many industrial sectors, especially in highly competitive areas with also the presence of a high level of substitution. Nevertheless, these theories can be useful as well as a support to decision making in slower paced sectors, as railways. In this article the case study of various highly innovative projects in railways sector will be addressed, from the point of view of innovation management and design theory, using TRIZ and some derivatives as General Theory of Innovation (G. Yezersky) .The systems under analysis are, respectively: High speed train TGV, $1^{\text {st }}$ driverless metro VAL, tramway ground power supplying, intermodality solutions, Aerotrain, Personal Rapid Transit, Swiss Metro, Hyperloop.
\end{abstract}

Keywords: disrupting innovation, railways, governmental role.

\section{Introduction}

Since the origins, TRIZ theory has been used for solving technical problems [1]. Nevertheless, the application of this theory to other disciplines has been largely diffused, spacing from science, to business and even politics [2,3]. The scope of this paper is then to see how TRIZ together with innovation management theory can be used for decision making and technology forecasting on a specific topic that is the potential development of disruptive transport systems. In this paper disruptive innovation theory will be introduced, then a general approach to technology forecasting will be provided, with application to case studies. Finally, comparisons will be done with some indication for future steps. The systems under analysis are, respectively: High speed train TGV, $1^{\text {st }}$ driverless metro VAL, tramway ground power supplying, intermodality solutions, Aerotrain, Personal Rapid Transit, Swiss Metro, Hyperloop.

\section{Disruptive innovation theory}

The concept of disruptive innovation has been firstly created by Clayton C. Christensen from Harvard relating the model of innovation to the competitive position of the company on the market. According to [4] "Disruption describes a process whereby a smaller company with fewer resources is able to successfully challenge established 
incumbent businesses. Specifically, as incumbents focus on improving their products and services for their most demanding....Entrants that prove disruptive begin by successfully targeting those overlooked segments, gaining a foothold by delivering moresuitable functionality - frequently at a lower price. Incumbents, chasing higher profitability in more-demanding segments, tend not to respond vigorously.."

This concept is very powerful and at the same time simple: the company has a limited choice about the kind of innovation to pursue, according to its position on the market as leader, or challenger. Amongst the case studies cited by Clayton C. Christensen, the hard disk, milling plants...

Today Disrupting innovation theory is used mostly for strategic planning, in small and large companies, as INTEL.

\section{Design theory applied to technology forecasting and decision making; its coupling with disruptive innovation theory}

As described on a previous article from Bersano, Fayemi and al. [5], most used approach for forecasting is the classical prospective approach; this has various limitations (LCPx), that are overcome by the use of logistic curve and TRIZ theory, giving origin to a New Concept development Approach.

The following figure provides an overview on this approach, structured in various phases:

- Preparatory phase, in order to understand problem owner goals and expectation for the study, using Synectics theory [6];

- Phase A-B analysing the product and its surrounding systems, using typical TRIZ tools as Laws of Engineering System Evolution (LESE), System Operator Tool, Relevent analysis from GTI [7] and analysing future applications, using s-curves and expert interviews couples with statistical tool

- Phase $\mathrm{C}$ focused on inventive phase for new solutions, using TRIZ

- Phase D concerning the reinforcement of selected inventive ideas and development, both according to [6] and more in general to Project management best practise [8].

As described in chapter 2, the disrupting innovation theory can be used to assist the marketing and strategic process of the forecasting approach. Basically, the alternatives from the point of view of the company are two:

If the company is leader on the market, an incremental innovation approach will be preferred; then, all inventive ideas too far from currently in house products and services will be delayed or suppressed; if the company is an outsider, breakthrough innovation will be preferred as an internal strategy in order to create a strong differentiation with incumbents. In the following chapter, an example around railways systems will be developed. 


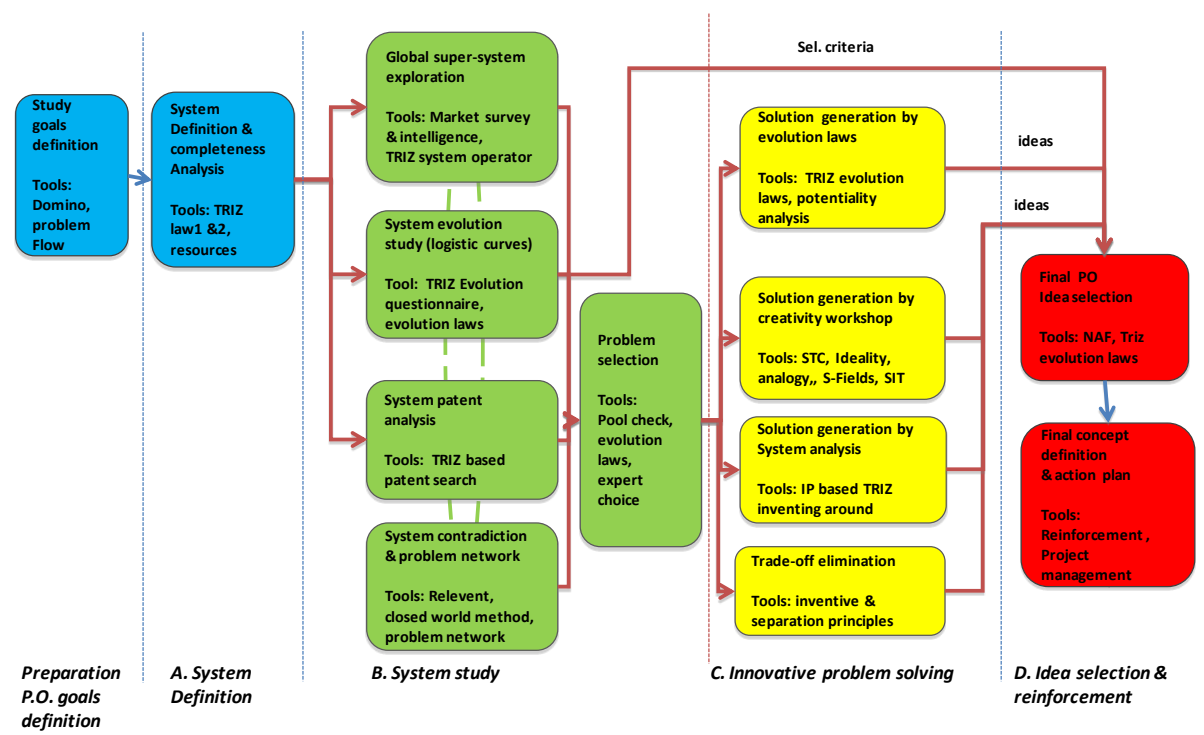

Figure 1. Schematic process for technology forecasting

\section{Case study: railways transport systems}

Transport systems exist since 10000 years, with the development of first wooden boats (running on water). Then, from 3000 B.C, it started the development of first wheel chariots (running on ground). Since then, other transport systems were developed running over different means, respectively the trains on rails and airplanes on air. Most recently, a new transportation system has been imagined, the Hyperloop [9]. According to its inventors, it would be the $5^{\text {th }}$ transportation system beside the existing ones. The research question posed is then the following: which are the probability of success of this radically new transport system in and existing and consolidated market? In order to answer to this question, technology forecasting based on TRIZ and the disruptive innovation theory will be here applied.

\subsection{TRIZ Law 1 application and extension}

According to TRIZ theory [1], the Laws of system evolution of systems (LESE) describes the conditions for the best development of systems. As an application example, the law $n^{\circ} 1$, describe the main components of a ground transport system. The following diagram describes the key elements of a transport system for a freight train and the evolution of systems. 


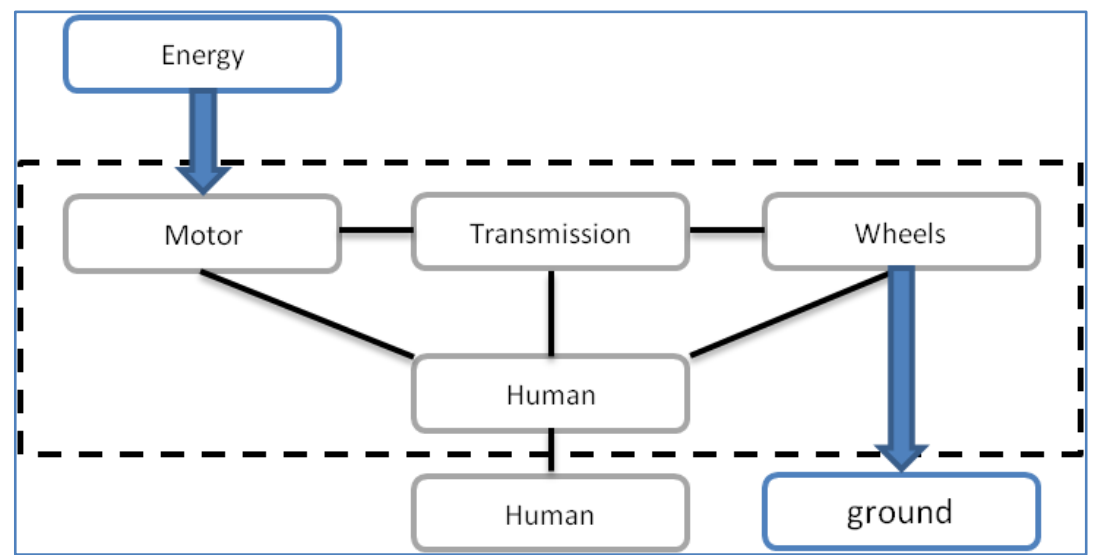

Figure 2. Application of Law $n^{\circ} 1$ to transport system

In the following tables, the simplified evolution of system's elements is mapped in time (for cars and railways).

Table 1. Elements for Law 1 applied to cars.

\begin{tabular}{|l|l|l|l|l|l|l|l|l|}
\hline SYSTEM & MOTOR & TRANSMISSION & TOOL & $\begin{array}{l}\text { CONTROL } \\
\text { ELEMENT }\end{array}$ & $\begin{array}{l}\text { DECISION } \\
\text { ELEMENT }\end{array}$ & $\begin{array}{l}\text { Energy } \\
\text { source }\end{array}$ & Road & Success \\
\hline $\begin{array}{l}\text { Chariot (3000 } \\
\text { B.C. })\end{array}$ & $\begin{array}{l}\text { Horse } \\
(\mathrm{s})\end{array}$ & $\ldots$ & $\begin{array}{l}\text { Full } \\
\text { Wheel }\end{array}$ & Driver & Driver & Food & Earth & $\mathrm{Y}$ \\
\hline (2000 .B.C.) & & & $\begin{array}{l}\text { Rays } \\
\text { wheel }\end{array}$ & Driver & Driver & & & $\mathrm{Y}$ \\
\hline $\begin{array}{l}\text { Cugnot steam } \\
\text { engine (1771) }\end{array}$ & $\begin{array}{l}\text { Steam } \\
\text { engine }\end{array}$ & $\begin{array}{l}\text { Mechanical } \\
\text { transmission }\end{array}$ & $\begin{array}{l}\text { Rays } \\
\text { wheel }\end{array}$ & Driver & Driver & Coal & & $\mathrm{N}$ \\
\hline Car & $\begin{array}{l}\text { Gas } \\
\text { engine }\end{array}$ & $\begin{array}{l}\text { Mechanical } \\
\text { transmission }\end{array}$ & Tires & Driver & Driver & & & $\mathrm{Y}$ \\
\hline
\end{tabular}

Analyzing the historically evolution of rail transportation, it is noted that:

- The evolution of the system is linked to the evolution of motor element

- The energy sources and running infrastructure, that are external elements in interface with the law 1 model of the system (i.e. the super system), are critical for the success of the new system

There is the need to add some external elements of the analysis, to help understand why some systems survive and other not, behind the technical aspects...this will be realized using innovation management theory later. 
Table 2. Elements for Law 1 applied to railways.

\begin{tabular}{|c|c|c|c|c|c|c|c|c|}
\hline SYSTEM & MOTOR & TRANSMISSION & TOOL & $\begin{array}{l}\text { CONTROL } \\
\text { ELEMENT }\end{array}$ & $\begin{array}{l}\text { DECISION } \\
\text { ELEMENT }\end{array}$ & $\begin{array}{l}\text { Energy } \\
\text { source }\end{array}$ & Road & Success \\
\hline \multirow[t]{4}{*}{$\begin{array}{l}\text { Locomotive } \\
(1801)\end{array}$} & $\begin{array}{l}\text { Steam } \\
\text { engine }\end{array}$ & mechanical & $\begin{array}{l}\text { Steel } \\
\text { wheels }\end{array}$ & driver & driver & coal & $\begin{array}{l}\text { Steel } \\
\text { rails }\end{array}$ & $\mathrm{Y}$ \\
\hline & $\begin{array}{l}\text { Electri- } \\
\text { cal } \\
\text { motor } \\
(1834)\end{array}$ & & & & & battery & & $\mathrm{N}$ \\
\hline & & & & & & $\begin{array}{l}\text { Catena- } \\
\text { ry } \\
(1881)\end{array}$ & & $\mathrm{Y}$ \\
\hline & $\begin{array}{l}\text { Diesel } \\
\text { engine } \\
(1931)\end{array}$ & & & & & Oil tank & & $\mathrm{Y}$ \\
\hline $\begin{array}{l}\text { Shinkansen } \\
\text { (1964) }\end{array}$ & & & & & & $\begin{array}{l}\text { Catena- } \\
\text { ry } 25 \mathrm{kV}\end{array}$ & & $\mathrm{Y}$ \\
\hline $\begin{array}{l}\text { TGV } \\
(1981)\end{array}$ & $\begin{array}{l}\text { SofA el } \\
\text { motors }\end{array}$ & & & & & & & $\mathrm{Y}$ \\
\hline $\begin{array}{l}\text { Aerotrain(1 } \\
971)\end{array}$ & $\begin{array}{l}\text { Gaz } \\
\text { turbine }\end{array}$ & mechanical & $\begin{array}{l}\text { Air } \\
\text { cush- } \\
\text { ion }\end{array}$ & driver & driver & gaz & $\begin{array}{l}\text { Con- } \\
\text { crete } \\
\text { ele- } \\
\text { vated }\end{array}$ & $\mathrm{N}$ \\
\hline $\begin{array}{l}\text { VAL } \\
(1978)\end{array}$ & & & & $\begin{array}{l}\text { Automat- } \\
\text { ic Train } \\
\text { Opera- } \\
\text { tion }\end{array}$ & & & & $\mathrm{Y}$ \\
\hline $\begin{array}{l}\text { SwissMetro } \\
(2005)\end{array}$ & $\begin{array}{l}\text { El mo- } \\
\text { tors }\end{array}$ & mechanical & maglev & & & $\begin{array}{l}\text { electrici- } \\
\text { ty }\end{array}$ & $\begin{array}{l}\text { Vac- } \\
\text { uum } \\
\text { tube }\end{array}$ & $\mathrm{N}$ \\
\hline
\end{tabular}

\subsection{System Operator Tool application and extension}

System Operator Tool has been described in [1]. It is well adapted for this kind of analysis, identifying trends, advantages and disadvantages. The following table is an extraction of a larger table developed for locomotive for freight transportation. 
Table 3. Elements for Law 1

\begin{tabular}{|c|c|c|}
\hline Super-system trends & System trends & Sub-systems trends \\
\hline $\begin{array}{l}\text { - Complete trains termi- } \\
\text { nals } \\
\text { - Simplicity/ Performance/ } \\
\text { Standardization } \\
\\
\text { - Rail sorting stations } \\
\text { - modernization + recon- } \\
\text { version } \\
\text { - fast actions, high perfor- } \\
\text { mances, } \\
\text { competitiveness } \\
\text { - Mega-hubs development } \\
\text { - Rail terminal and sorting } \\
\text { station } \\
\text { - Multimodal (road) termi- } \\
\text { nal station } \\
\text { - Logistic platform } \\
\text { - European networks in- } \\
\text { teroperability }\end{array}$ & $\begin{array}{l}\quad \text { - Product used to } \\
\text { meet very high capaci- } \\
\text { ty demand of freight } \\
\text { market } \\
\text { - Provide more safety } \\
\text { and reliable operation. } \\
\text { - Increase the travels } \\
\text { frequency } \\
\text { - Higher travel speed } \\
\text { - Energy source } \\
\text { change (more sustain- } \\
\text { able, renewable ener- } \\
\text { gy sources) }\end{array}$ & $\begin{array}{l}\text { - Increase the autonomy (possibil- } \\
\text { ity of crossing sections without cate- } \\
\text { nary) } \\
\text { - Need to store more energy } \\
\text { - Need to reduce the losses } \\
\text { - Need to reduce the volume } \\
\text { - Need to reduce the mass } \\
\text { - Minimize the passive components } \\
\text { - Lighten the transformers } \\
\text { - Active filtration } \\
\text { - Middle-frequency transformers } \\
\text { - Integration technologies (converg- } \\
\text { ing to digital, full functional digital } \\
\text { communication) } \\
\text { - Better brake performance } \\
\text { - Distributed traction power }\end{array}$ \\
\hline
\end{tabular}

\subsection{General Theory of Innovation application for disrupting value chains}

The history of innovation is full of failures, even for very promising systems; amongst most cited failed innovations, Segway, Google Glass, Sony Betamax [10][11]. Various scholars analyzed the reason of failure, focusing on innovation value chain [12]. As an example, let's take the Betamax. A much better technical system than VHS, capable of high quality image and sound videotapes, the system was killed by Hollywood because of the risk of high quality copy of the movies, and by the retailers of video, that were already equipped with competing VHS system. Others have focused on the structure of the market and the potential impact on existing value chain, without unfortunately providing a methodological approach for evaluation. Amongst TRIZ theory and related developments, there is the Relevent analysis as developed par G. Yezersky [7]. According to this tool, the system to be improved is analyzed according to the following elements:

- Identification of real customer and his extra value moment (behind expectations)

- Identification of application scenarios

- Identification of potential problems at different scenarios steps, partial solutions and secondary related problems

- Selection of innovative problems to be solved

Due to its clear sequential and logical approach, it is an easy way to represent a network of problems for a complex system. The following figure is an extraction of a 
representation of this analysis applied to the value chain as an example, of Amazon delivering some parcel to customers. In this example, problems concerning cost of expedition by rail and distance to loading-unloading are identified, nevertheless the analysis must include: final customer and all intermediate players and infrastructure providers.

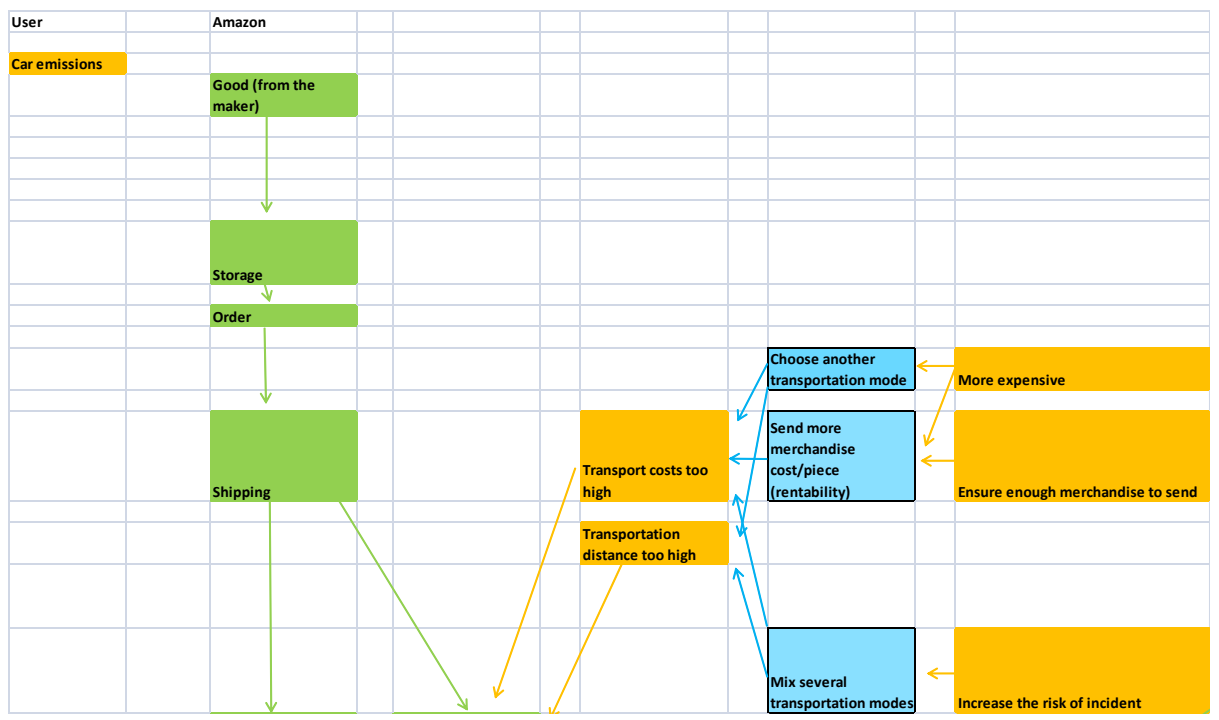

Figure 3. Application of Relevent analysis on freight transportation (an extract)

\subsection{Disrupting innovation and the role of governments}

Disrupting innovation is in general capital intensive; considering the transport sector, there are various certifications to be obtained before allowing the transportation of people, and huge validation tests. Therefore, innovators in this field are really crossing the valley of the death of innovation [13]. In this situation, if the value chain is against a disrupting innovation, what are the chances of success? A positive outcome to this kind of innovation can come from the government. According to Prof. M. Mazzucato, [14], "government investment played a central role in developing nearly all of the technologies that make the iPhone a smart phone: the Internet, GPS, touch screens, and the advances in voice recognition underlying Siri". It is then possible to create a viability check-list in order to identify which innovation is more suitable to succeed in a complex and conservative market as the public transport sector.

The following table is a synthetic check-list for a transportation project, based on some major innovation in the last 50 years.

The system level involves large value chains to be impacted, then lower probability of success. The cost is high reduces as well the probability of success. If the innovation is pushed to an incumbent company, the company will try to disregard it. The state support is the necessary element for the development of the first transport sys- 
tem, that if successful it will reduce costs and will become a real competitor in mature transport world. Based on this analysis, for Hyperloop promoters it is necessary to focus the activity firstly on finalizing the design of the system (making it work) and in parallel on a strong lobbying action on regional and national governments.

Table 4. Historical analysis on the check-list for success for a new transport system.

\begin{tabular}{|l|c|l|l|c|c|}
\hline INNOVATION & $\begin{array}{c}\text { SYSTEM } \\
\text { LEVEL }\end{array}$ & COST & COMPANY & $\begin{array}{l}\text { STATE } \\
\text { SUPPORT }\end{array}$ & SUCCESS \\
\hline TGV & SYS & HIGH & INCUMBENT & Y & Y \\
\hline VAL & SYS & HIGH & OUTSIDER & Y & Y \\
\hline GROUND FEED & SUB & MID & OUTSIDER & Y & Y \\
\hline INTERMODALITY & SUB & LOW & OUTSIDER & Y & Y \\
\hline AREOTRAIN & SYS & HIGH & OUTSIDER & N & N \\
\hline ARAMIS PRT & SYS & HIGH & OUTSIDER & N & N \\
\hline SWISSMETRO & SYS & HIGH & OUTSIDER & N & N \\
\hline HYPERLOOP & SYS & HIGH & OUTSIDER & $?$ & $?$ \\
\hline
\end{tabular}

\section{Conclusions}

The history of TRIZ theory is related to the solution of technical problems, in a market free environment as former URSS. In this perspective, in classical TRIZ marketing and company strategy are not considered at all.

Various steps in this direction have been realized in modern TRIZ, and the current paper is exploring the synergy between different theories with a specific focus at company strategy for future developments. Specifically, a general approach for technology forecasting is presented, providing a lecture key for companies on the selection of innovation projects.

Then, a case study is given on railways, started by the questioning about the potential success of Hyperloop. For this specific point, the need of a governmental support seems mandatory for the development and penetration of this very innovative system.

As next steps, the previous table would be enlarged with more case studies, and would be also adapted to other sectors. 


\section{References}

1. Savranksy, S.: Engineering of Creativity - Introduction to TRIZ Methodology of Inventive Problem Solving. New York: CRC Press; 2000.

2. Zlotin, B , Zusman, A.: ARIZ on the Move. The Triz Journal (1999).

3. Souchkov, TRIZ and Systematic Business Model Innovation TFC (2010)

4. Christensen, C. C., \& al.: What Is Disruptive Innovation?. HBR (2015).

5. Schöfer, M., Bersano, G., Fayemi, P, Calvez, J.: Methodological support for prospective studies in New Concept Development. Triz Future Conference (2014).

6. Nolan V,: The innovator's handbook - The skills of innovative management. Time Warner (1989

7. Yezerski G,: General Theory of Innovation and Its Applications. In: C Grundlach, U Lindemann H Ried, editors. Proceedings of the TRIZ Future Conference;. p. 283-287. (2007)

8. Musk, E.: Hyperloop Alpha document (2013)

9. Chiocchio, F., Forgues, D., Paradis, D., \& Iordanova, I. (2011). Teamwork in integrated design projects: understanding the effects of trust, conflict, and collaboration on performance. Project Management Journal, 42(6), 78-91

10. Mann, D.: On innovation timing. The Triz Journal (2007).

11. Bauer, R.: Failed Innovations: 5 decades of Failure? Vol. 20, No. 1, Symposia Anniversary Edition (2014), pp. 33-40

12. McElheran, K.: Taking a Value-Chain Perspective on Innovation. MIT Sloan Blog (2016)

13. Ford, G. \& Al: A Valley of Death in the Innovation Sequence: An Economic Investigation. Research evaluation (2007)

14. Mazzucato, M.: What is government's role in sparking innovation?. WEF, (2015) 